\title{
Kewajiban Orang Tua terhadap Anak dalam Perspektif Islam
}

\author{
Iim Fahimah
}

\author{
IAIN Bengkulu \\ J1. Raden Fatah Pagar Dewa Kota Bengkulu
}

\begin{abstract}
Obligations of Parents to Children in the Islamic Perspective. Humans are created by God to worship and worship him, either worship is directly related to God, or ghairu worship is related to humans but intended as a social worship. All that is done is on the basis of obligations as beings who are given responsibility as caliphs on this earth. In order to manifest the responsibility of a caliph properly, the tools and tools to implement it must be present and correct. The device is in the form of knowledge and expertise. Furthermore, related to the parents' obligation to their children, the obligation is to prepare children to be a generation that is strong and resilient both physically and mentally. Physically, parents must provide and prepare food, drinks, clothing, and shelter. Whereas spiritual needs which include identity such as parents are required to provide the child's name and nasab from parents. In addition, parents are also obliged to provide education for children so that children are able to perform their obligations as servants and and be able to protect themselves from the evil of His creatures.
\end{abstract}

Abstrak: Manusia diciptakan oleh Allah untuk menyembah dan beribadah kepadanya baik itu ibadah mahdlah yang berhubungan langsung dengan Allah, ataupun ibadah ghairu mahdlah yang berhubungan dengan manusia tapi diniatkan sebagai ibadah sosial. Semua yang dilakukan itu adalah atas dasar kewajiban sebagai makhluk yang diberikan tanggung jawab sebagai khalifah di muka bumi ini. Dalam rangka mengejawantahkan tanggung jawab seorang khalifah dengan benar maka perangkat dan alat untuk melaksanakannya harus ada dan benar. Perangkat itu berupa pengetahuan dan keahlian. Selanjutnya berkaitan dengan kewajiban orang tua terhadap anaknya, maka kewajibannya adalah mempersiapkan anak untuk menjadi generasi yang kuat dan tangguh baik fisik maupun mental. Secara fisik maka orang tua wajib memberikan dan menyiapkan makanan, minuman, pakaian dan tempat tinggal. Sedangkan kebutuhan rohani 
yang mencakup identitas seperti orang tua wajib memberikan nama anak dan nasab dari orang orang tua. Selain itu, orang tua juga wajib memberikan pendidikan terhadap anak, agar anak mampu melakukan kewajibannya sebagai seorang hamba dan dan mampu melindungi dirinya dari kejahatan makhluk-Nya.

\section{Pendahuluan}

Anak sebagai sumber kebahagian dan penyejuk hati, anak adalah amanah terbesar yang Allah berikan kepada setiap orang tua di dunia. Karenanya, anak adalah tanggung jawab orang tua. Masa depan anak sebagiannya bergantung pada pola asuh dan pendidikan yang diberikan orang tua. Anak adalah titipan Allah, sebagai titiapan maka bagi orang tua yang dititipi agar merawat titipannya dengan baik, dengan merawat mengasuh dan memberikan segala sesuatu yang membuat titipan tetap terawat dan sesuai dengan harapan penitip kepada yang ditipi. Sebagai makhluk yang paling sempurna manusia dipilih oleh Allah sebagai khalifah di muka bumi ini. Sebagai seorang khalifah maka menjadi suatu keharusan memahami segala yang diamanahkan di muka bumi ini oleh Allah, termasuk mengetahui dan menjalankan amanah sebagai orang tua bagi anak-anaknya. Mengurus segala keperluan anak semenjak dilahirkan adalah bagian dari kewajiban orang tua, akan tetapi terkait tanggung jawab manusia di muka bumi ini, maka untuk mengisi, menjaga, dan melestarikan alam yang ada di bumi ini perlu pengetahuan dan ketermpilan. Sejatinya manusia juga sebagai hamba yang diciptakan Allah untuk beribadah dan menyembah kepada Alah. Oleh karenanya sebagai orang tua maka berkewajiban mengantar anak-anaknya utuk dapat mengimplementasikan dan mewujudkan tujuan dan tanggung jawab sebagai seorang hamba.

\section{Kewajiban Orang Tua terhadap Anak}

Pada hakikatnya, semua orang tua sangat menaruh harapan dari keberhasilan anaknya ketika dewasa. Tidak seorangpun yang menginginkan 
$\begin{array}{lll}\text { anaknya gagal } & \text { dalam } & \begin{array}{l}\text { menurut ajaran Islam adalah } \\ \text { pendidikannya. }\end{array} \\ \text { Untuk } & \text { sebagai berikut: } & \end{array}$ merealisasikan harapan tersebut, orang tua senantiasa berusaha semaksimal mungkin untuk memberikan yang terbaik yang mencakup segala hal, baik perhatian, nutrisi, dan pendidikan anaknya. Dalam Islam, anak yang sedang tumbuh dan berkembang mempunyai hak untuk dicukupi kebutuhan akan makan dan minum oleh orang tuanya agar menjadi orang yang sehat normal dan kelak menjadi insan yang cerdas dan kreatif.

Anak yang sedang berkembang harus diperlakukan secara penuh perhatian oleh orang tua dan pendidiknya karena anak bukanlah orang dewasa yang berbadan kecil. Perkembangan psikisnya masih sangat terbatas sehingga tidak sepatutnya jika ia harus mengerjakan pekerjaan orang dewasa dan anak tidaklah boleh matang sebelum waktunya. Tugas orang tua terhadap anak adalah dengan memberikan hakhak kepadanya dengan baik. Adapun diantara hak anak

\section{A. Kewajiban Memberikan Nasab}

Secara etimologi nasab berarti hubungan, dalam hal ini adalah hubungan darah antara seorang anak dengan ayah dan ibunya karena sebab-sebab yang sah menurut syara', yakni jika sang anak dilahirkan atas dasar perkawinan dan dalam kandungan tertentu yang oleh syara' diakui keabsahannya. Dengan demikian, setiap anak yang lahir langsung dinasabkan pada ayahnya agar lebih menguatkan perkawinan kedua orang tuanya.

Berkaitan dengan hak nasab adalah hak mendapatkan nama dari orang tuanya. Ketika anak dilahirkan, orang tua memilihkan sebuah nama untuknya, dengan demikian ia dapat dikenal oleh orang-orang di sekelilingnya. Islam telah menetapkan dasar hukum yang jelas berkaitan dengan perkara nama tersebut. Pemberian nama itu dapat dilakukan pada hari 
Kewajiban Drang Tua terhadap Anak dalam Perspektif Islam

pertama setelah kelahiran anak, boleh diakhirkan hingga hari ketiga atau hari ketujuh ${ }^{1}$

\section{B. Kewajiban Memberikan Susu (rada'ah)}

Air susu ibu atau yang lebih dikenal dengan sebutan ASI adalah nutrisi terbaik untuk sang bayi. Air susu ibu merupakan makanan bayi yang paling sempurna, sebab tidak hanya kaya akan zat pertumbuhan, tetapi sekaligus berisi zat-zat penangkal atau melindungi berbagai macam penyakit. Air susu ibu bukan hanya merupakan sumber nutrisi bagi seorang bayi saja, tetapi juga merupakan zat anti kuman yang kuat karena adanya beberapa faktor yang bekerja secara sinergis membentuk suatu system biologis untuk membunuh kuman.

Air susu ibu adalah makanan alamiah bayi. Ia steril dan suhunya secara alamiah pula sesuai dengan kebutuhan bayi. Cara memberikan air susu ibu juga sederhana dan jika diberikan oleh ibu kandungnya sendiri maka akan bermanfaat ganda, yaitu untuk kepentingan biologis bayi dan sekaligus baik untuk membentuk sikap dan kepribadian anaknya kelak, sebab didalam penyusuan terdapat mekanisme emosional yang membuat ibu dekat dengan anaknya. Setiap bayi yang lahir berhak atas susuan pada periode tertentu dalam kehidupannya, yaitu periode pertama ketika ia hidup. Adalah satu fitrah bahwa ketika bayi dilahirkan ia mebutuhkan makanaan yang paling cocok dan paling baik untuknya, yaitu air susu ibu. Secara klinis, terbukti bahwa air susu ibu mengandung unsurunsur penting dan vital yang dibutuhkan bayi bagi perkembangannya. Air susu ibu berdaya guna untuk memberikan segala kebutuhan bayi untuk tumbuh dengan sehat dan melindunginya dari berbagai penyakit.

Berkaitan dengan kewajiban orang tua untuk memberikan air susu tercermin dalam al-Qur'an: Para ibu hendaklah menyusui anak-anaknya selama 2 tahun penuh, yaitu bagi 
Jurnal Hawa Vol. I No. I Januari-Juni 20IG

yang ingin menyempurnakan penyusuan (al-Baqarah / 2:233).

Menurut Ibnu Qayyim alJauziyah, ayat diatas menunjukan beberapa hukum, pertama bahwa masa penyusuan yang sempurna berlangsung selama 2 tahun. Hal ini di tunjukkan dengan kata "kamilaini" yang berarti (penuh/sempurna) agar tidak ditafsirkan satu tahun lebih. Kedua, jika kedua orang tua ingin menyudahi sebelum masa 2 tahun, maka hal itu harus dimusyawarahkan antara ibu dan bapak serta tidak boleh membahayakan perkembangan anak. ${ }^{2}$

\section{Kewajiban Mengasuh (hadlanah)}

Setiap anak yang
dilahirkan oleh berhak mendapatkan asuhan, yakni memperoleh pendidikan dan pemeliharaan untuk mengurus makan, minum, pakaian dan kebersihan si anak pada periode kehidupan pertama (sebelum ia dewasa) yang dimaksud dengan pemeliharaan di sini dapat berupa pengawasan dan penjagaan terhadap keselamatan jasmani dan rohani anak dari segala macam bahaya yang mungkin dapat menimpanya agar tumbuh secara wajar. Anak juga membutuhkan pelayanan yang penuh kasih sayang dan pemenuhan kebutuhan berupa tempat tinggal dan pakaian. Oleh karena itulah pada usia balita seorang anak belum mempunyai kemampuan, sehingga kehidupan mereka sangat bergantung pada orang lain yang dewasa, yaitu ibu dan bapaknya. Hak pemeliharaan anak yang dipikulkan pada orang tua adalah dimaksudkan agar anak terhindar dari hal-hal yang dapat menjerumuskan mereka kedalam kemurkaan tuhan ${ }^{3}$ berkaitan dengan hak anak yang harus mendapatkan perawatan dan asuhan dengan penuh kasih sayang rasulullah saw bersabda: "Bukan termasuk golongan kami orang yang tidak mengasihi yang kecil dan tidak mengenal hak orang yang lebih besar," (H.R.Abu Dawud). Dengan demikian, hak asuh bagi setiap anak adalah agar di rawat dengan penuh ksih sayang, 
lim Fahimah

Kewajiban Drang Tua terhadap Anak dalam Perspektif Islam

diperhatikan dan dipilihkan makanan dan minuman yang baik serta dilindungi dari berbagai penyakit demi kelangsungan pertumbuhan dan perkembangan hidupnya.

Dengan kasih sayang, anak akan tumbuh dengan kepribadian yang sempurna dan sehat sehingga menghasilkan manusia-manusia yang baik. Dengan memperhatikan makanan, minuman, dan kesehatannya berarti akan menciptakan manusia-manusia yang sehat dan kuat jasmani dan rohaninya.

D. Kewajiban Memberikan Nafkah dan Nutrisi yang Baik

Menurut ajaran Islam,
seorang anak berhak
mendapatkan nafkah, yakni
pemenuhan kebutuhan pokok.
Nafkah terhadap anak bertujuan
untuk kelangsungan hidup dan
pemeliharaan kesejahteraannya.
Dengan demikian, anak terhindar
dari kesengsaraan hidup di
dunia, karena mendapatkan
kasih sayang orang tuanya
melalui pemberian nafkah tersebut. Hak mendapat nafkah merupakan akibat dari nasab, yakni nasab seorang anak terhadap ayahnya menjadikan anak berhak mendapatkan nafkah dari ayahnya, berdasarkan firman Allah SWT :

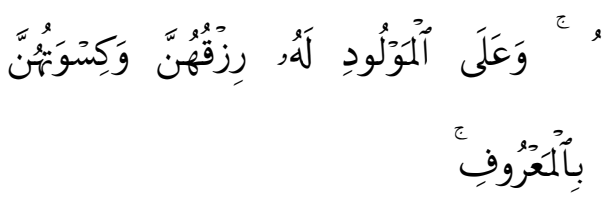

“.. Dan kewajiban ayah memberi makan dan pakaian kepada para ibu dengan cara yang baik ... (alBaqarah /2: 233).

Disamping hak mendapatkan nafkah, seorang anak juga berhak memperoleh gizi yang baik dari orang tuanya. Gizi mempunyai peran yang sangat besar dalam membina dan mempertahankan kesehatan seseorang. Ini adalah kewajiban setiap manusia untuk memelihara kesehatan baik kesehatan fisik maupun kesehatan mentalnya. Maksudnya adalah sudah menjadi kewajiban seseorang untuk memelihara kesehatan 
jasmani dan rohaninya sehingga dapat berfungsi sebagaimana mestinya. Di dalam ilmu kesehatan, seorang anak memerlukan sumber makanan yang bergizi untuk pertumbuhan dan perkembangannya. Gizi yang cukup merupakan faktor utama sebagai penunjang bagi perkembangan kecerdasan anak.

Seorang ibu yang sedang mengandung, sangat membutuhkan gizi yang baik, selain untuk kesehatan si ibu sendiri, juga untuk kesehatan calon bayinya. Karena bayi yang di kandungnya sangat tergantung pada makanan dari ibunya. Bila makanan ibu banyak mengandung gizi, maka kemungkinan besar bayi yang di kandungnya juga akan sehat dan cerdas. Perlu diketahui bahwa bayi makan melalui placenta, yang merupakan media penghubung antara ibu dan anak yang mempunyai fungsi sebagai penerus zat makanan.

$\begin{array}{lllr} & \text { Ketergantungan } & \text { bayi } \\ \text { yang seperti itulah maka } & \text { mang di } & \text { makanan } \\ \text { makanan } & \text { yang } & \text { memegang }\end{array}$

peranan dalam pemeliharaan kesehatan bayi. Seorang ibu yang memperhatikan gizi makanannya maka kemungkinan besar untuk melahirkan bayi yang sehat dapat terwujud. Begitu juga sebaliknya, bila ibu tidak memperhatikan makanan, maka bayi yang dilahirkan akan tidak sehat. Begitu pentingnya gizi sampai alQur'an menyuruh kepada semua umat manusia untuk selalu memperhatikan makanan terutama makanan yang baik dan mengandung gizi sebagaimana firman Allah:

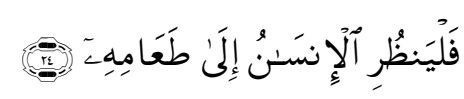

"Maka hendaklah manusia memperhatikan makanannya" (Abbas /80: 24).

Dari penjelasan mengenai makanan bergizi di atas, dapat kita simpulkan bahwa keadaan gizi bagi seorang ibu semasa kehamilan memiliki pengaruh bagi pembentukan kecerdasan, moral dan bakat seorang anak. Hal itu karena otak dan system saraf anak terbentuk dari makanan. Jenis makanan yang 
Kewajiban Drang Tua terhadap Anak dalam Perspektif Islam

berbeda memiliki pengaruh tersendiri bagi kesehatan bayi. Oleh karena itu, Islam menegaskan adanya pengaruh makanan pada seorang apa lagi terhadap seorang ibu yang sedang hamil. Seorang ibu yang sedang hamil dianjurkan untuk selalu memakan makanan yang banyak mengandung gizi karena disamping untuk kesehatan dirinya juga untuk bayinya.

Berkaitan dengan pembahasan di atas maka keadaan gizi ibu yang baik adalah dasar utama bagi kesehatan bayi. Seorang ibu yang ingin melahirkan bayi yang sehat harus memperhatikan apa yang ia makan. Konsumsi gizi yang kurang memadai dapat mengakibatkan gangguan pertumbuhan bayi dan dapat memberikan dampak buruk terhadap ibu sendiri. Dalam pandangan Islam, ada hubungan langsung antara makanan yang halal dan sehat dengan perbuatan-perbuatan baik. Jenis makanan yang halal dan memiliki nilai kesehatan yang tinggi mempunyai pengaruh terhadap fisik dan juga dalam pembentukan kualitas kepribadian anak sebagaimana firman Allah :

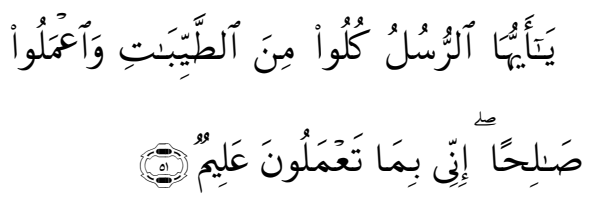

"Wahai rasul, makanlah yang baik dan kerjakanlah amal saleh, sesungguhnya aku maha mengetahui apa yang kamu kerjakan" (alMukminun /23: 51).

Ayat di atas menunjukkan bahwa Islam sangat perduli sekali terhadap umatnya sampai makan pun dianjurkan untuk mengkonsumsi makanan yang mengandung gizi begitu pentingnya gizi sehingga seorang ibu yang sedang masa hamil dan menyusuhi dianjurkan memperhatikan makanannya terutama yang mengandung gizi. Disamping itu, nafkah yang diberikan orang tua terhadap anak hendaklah dengan cara yang halal. Status makanan yang disuapkan ke dalam mulut anak 
akan membuat fisik dan akan mempengaruhi jiwa anak. ${ }^{4}$

\section{E. Hak Memperoleh Pendidikan}

Selain hak memperoleh nafkan dan nutrisi yang baik, seorang anak yang dilahirkan juga berhak mendapatkan pendidikan, yakni perhatian terhadap pendidikan dan pengajaran si anak agar kelak menjadi manusia yang berguna serta mempunyai kemampuan dan dedikasi hidup yang mampu dikembangkan di tengah-tengah masyarakat. Berbicara mengenai hak anak bagi orang tuanya, maka sebagai timbal balik pembicaraan mengenai kewajiban anak terhadap orang tuanya merupakan suatu keharusan. Hak pendidikan anak mencakup pendidikan jasmani dan rohani. Pendidikan jasmani adalah ajaran yang diberikan agar anak bisa merawat dirinya sehingga ia bisa hidup sehat, terhindar dari penyakit. Pendidikan rohani dimaksudkan agar anak mempunyai jiwa yang kuat dan sehat. ${ }^{5}$

$$
\text { Pada pendidikan yang }
$$

berlangsung di dalam lingkungan keluarga (informal), orang tua berperan sebagai pendidik. Orang tua dituntut mengetahui tentang ilmu agama atau ajaran-ajaran agama. Meskipun dalam kenyataannya masih banyak orang tua yang belum mengetahui tentang ajaran agama, bahkan banyak pula yang tidak pernah mengamalkannya, tapi hal tersebut bukan berarti mereka terlepas dari tanggung jawab terhadap pendidikan agama bagi anak-anaknya, karena masih dapat ditempuh dengan jalan lain, seperti mamanggil guru agama untuk memberikan les secara private bagi anaknya. Dalam lingkungan keluarga, pelaksanaan pendidikan agama bagi anakanak khususnya pada usia balita sangat tepat dengan memberikan contoh atau praktek-praktek pengamalan ajaran-ajaran agama, baik yang berkaitan dengan cara ibadah, akhlak maupun akidah dan keimanan.

Adapun urgensi penanaman pendidikan agama bagi anak adalah agar anak dapat 
Kewajiban Drang Tua terhadap Anak dalam Perspektif Islam

tumbuh dan secara berangsurangsur menghayati dan mengamalkan ajaran agama, terutama yang berkaitan dengan akhlak terhadap orang tua. Begitu susah payahnya orang tua yang membesarkan anaknya sehingga banyak ketentuan agama yang mewajibkan seorang anak untuk berbakti kepada orang tua. Firman Allah:

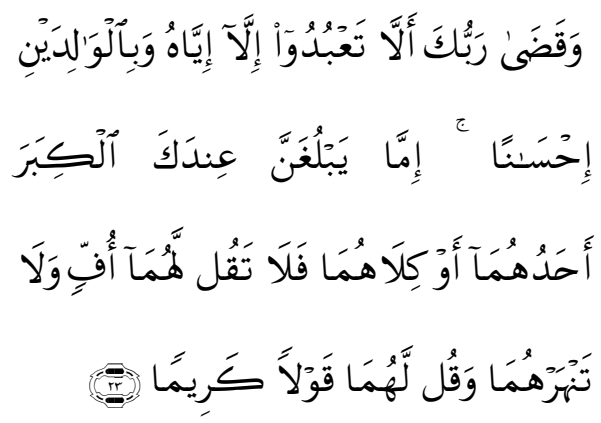

"Dan tuhanmu telah memerintahkan supaya kamu jangan menyembah selain dia dan hendaklah kamu berbuat baik kepda ibu bapakmu dengan sebaik-baiknya." (al-Isra' /17: 23).

Ayat diatas dengan jelas telah mengisyaratkan bahwa kewajiban berbuat baik kepada orang tua merupakan kewajiban kedua setelah keimanan. Betapa tinggi kedudukan orang tua di mata Islam hingga ungkapan syukur yang sudah seharusnya diberikan seorang hamba hanya kepada khaliqnya. Allah juga menganjurkan agar diberikan pula kepada kedua orang tuanya, sebagai mana firman Allah : Bersyukurlah kepadaku dan kepada ibu bapakmu, hanya kepada-Ku lah tempat kembali (Luqman/31: 14)

Begitu indahnya ajaran Islam dalam rangka membalas budi seorang anak kepada orang tuanya. Ungkapan-ungkapan dalam firman Allah tadi tersirat ajaran agar anak memenuhi kebutuhan kedua orang tuanya ketika mereka sudah mulai udzur dan jika memang keduanya membutuhkan. Kebutuhan disin bisa diartikan kebutuhan yang menyangkut jasmani dan rohani yang berupa kasih sayang.

Dengan demikian, sebenarnya sebelum badan dunia PBB mengeluarkan undangundang tentang hak anak, Islam sudah lebih dahulu memberikan hak kepada anak-anak. Dalam badan dunia PBB sebagaimana 
Jurnal Hawa Vol. I No. I Januari-Juni 20IG

tercantum pada Univesal declaration of Human Rights disebutkan dalam pasal 26 yang dapat dirinci sesuai dengan kebutuhan dan kepentingan anak berdasarkan perkembangan fisik dan mentalnya. Hak anak yang terutama adalah hak untuk memperoleh air susu ibu, kasih sayang orang tua dan orang dewasa dalam segala bentuknya. Disamping hak bermain dengan atau tanpa mempergunakan alat bermain yang bukan saja harus aman secara fisik biologis maupun psikologis. Hak anak lainnya adalah untuk memperoleh pendidikan formal, informal dan non formal. Apabila semua hak anak sudah dipenuhi oleh orang tuanya, maka insya allah anak akan tumbuh sehat, cerdas dan senantiasa mengamalkan ajaran-ajaran agama dengan baik dan benar.

III. Sikap Adil terhadap Anak dalam Keluarga

Dalam Kamus Besar Bahasa Indonesia disebutkan bahwa anak adalah manusia yang masih kecil. 6 Sementara itu, J.S. Badudu dan Sutan
Mohammad Zain mengatakan bahwa anak adalah keturunan pertama sesudah ibu bapak.7 Anak mempunyai kedudukan yang sangat penting bagi kehidupan manusia, karena ia menjadi pelanjut keberadaan manusia. Proses kegiatan ini terus berlanjut dari generasi ke generasi berikutnya. Dalam preoses ini anak berfungsi sebagai generasi penerus atau bisa disebut penyambung keturunan. ${ }^{8}$

Pada dasarnya seorang anak mempunyai kedudukan yang sama dengan anak yang lain. Rasulullah saw. Tidak pernah memandang bahwa anak ini mempunyai kedudukan yang lebih tinggi dengan anak lainnya. Beliau menyuruh umatnya untuk memperlakukan anaknya dengan adil sebagaimana sabdanya: "bertakwalah kepada allah dan bersikap adil terhadap anakanakmu.(H.R. Bukhori Muslim).

Mengacu pada hadits nabi tersebut, maka orang tua sepanjang masa dapat menerapkan dasar keadilan dan persamaan dalam kecintaan, 
$\lim$ Fahimah

\section{Kewajiban Drang Tua terhadap Anak dalam Perspektif Islam}

perlakuan, dan kasih sayang tanpa membeda-bedakan diantara anak-anaknya baik lakilaki maupun perempuan. Perlakuan tidak adil yang dilakukan orang tua terhadap anak akan menimbulkan perasaan kurang baik dan anak akan mengasumsikan berbagai macam perasaan yang sebetulnya justru akan merugikan kepada si anak itu sendiri dan selanjutnya akan merugikan pula kepada keluarganya. ${ }^{9}$

Dasar keadilan dan persamaan dalam keluarga juga merupakan salah satu sasaran alQuran. Al-Quran menetapkan prinsip-prinsip dan aturanaturan untuk membantu manusia mengatur hidupnya sehingga dapat memperbaiki kehidupannya. Di antara sasaran al-Quran itu adanya perlindungan terhadap hak-hak anak tanpa membeda bedakan antara satu dengan yang lain. Islam tidak membedakan hak antara individu yang satu dengan individu yang lain. Persamaan hak harus diberikan secara adil sekalipun terhadap anak-anak dalam hal ini, misalnya salah seorang anak laki-laki lebih disayangi dari pada anak perempuan, perlakuan tersebut merupakan hal yang bertentangan dengan pandangan Islam, sunnah dan konsep persamaan yang menjadi dasar hukum Islam.

Islam tidak membedakan antara laki-laki dan wanita karena keduanya adalah seimbang dan tidak ada seorangpun dapat melebihi yang lainnya kecuali karena kemuliaan amalnya sebagaimana firman Allah:

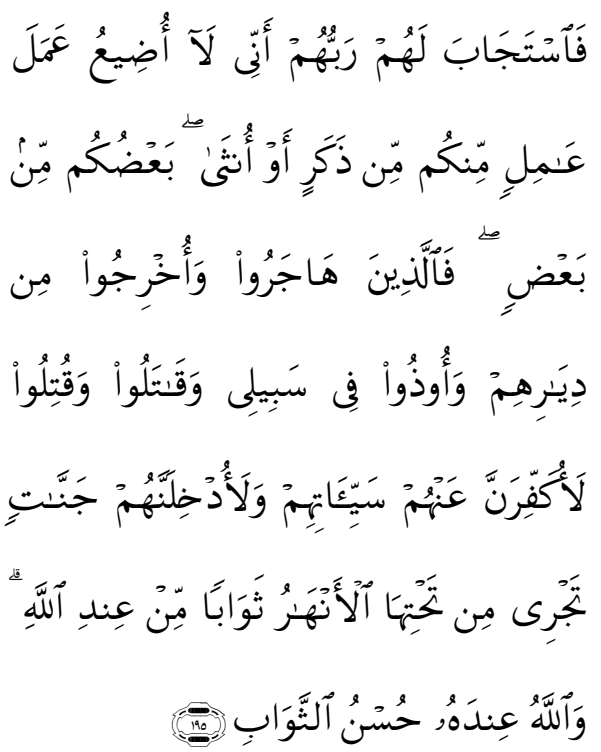


Jurnal Hawa Vol. I No. I Januari-Juni 20IG

"Maka Tuhan mereka memperkenankan permohonannya (seraya berfirman) "sesungguhnya aku tidak menyia-nyiakan amal orang-orang yang beramal diantara kamu, baik laki-laki atau perempuan karena sebagian kamu adalah turunan dari sebagian yang lain..." (Ali Imran /3:195).

\section{Kasih Sayang Orang Tua Terhadap Anak}

Allah sebagai maha pengatur telah menciptakan makhluknya sedemikian rupa, sehingga sudah merupakan hukum alam bahwa anak-anak membutuhkan dan selalu mendambakan kasih cinta dari orang tuanya. Kebutuhan seorang anak akan cinta dan kasih sayang, sama besarnya dengan kebutuhan fisik dan makanan. Demikian pula sebaliknya orang tua juga sangat mencintai dan menyayangi buah hatinya sehingga terbentuk sebah ikatan batin yang tidak dapat dihilangkan. Prof. Dr. Zakiyah Daradjat mengatakan bahwa yang sangat dibutuhkan anak bukanlah benda-benda atau hal- hal lahir tetapi jauh lebih penting dari itu adalah kepuasan batin merasa mendapat tempat yang wajar dalam hati ibu bapaknya. ${ }^{10}$

Seperti diketahui bahwa anak itu merupakan akibat dari hubungan ayah dan ibu. Orang tua diberikan Tuhan dengan kebaikan dan kasih sayang yang senantiasa memperkaya jiwa dan perasaan keterikatannya. Hubungan yang erat antara orang tua dan anak merupakan hubungan yang paling kuat dan mulia diantara hubunganhubungan yang lain. Cinta orang tua terhadap anak-anak memang tidak dapat diragukan lagi karena hal ini merupakan tanda ilahiyah dan berkah bagi manusia sebagaimana firman Allah.




Kewajiban Drang Tua terhadap Anak dalam Perspektif Islam

"Dan diantara tanda-tanda kekuasaan- Nya ialah Dia menciptakan untukmu istri-istri dari jenismu sendiri supaya kamu cenderung dan merasa tentram kepadanya. dan dijadikan-Nya diantaramu rasa kasih dan sayang." (al-Rum /30:21).

Menurut beberapa ahli tafsir, "kasih dan sayang" dalam ayat tersebut diartikan sebagai sesuatu yang menunjukan adanya anak yang memperkuat hubungan dengan orang tua. Orang tua selalu menanamkan rasa cinta yang tidak terbatas kepada anak-anaknya. Oleh karena itu, setelah anak dipelihara oleh kedua orang tuanya sejak kecil, maka setelah dewasa ia diperintahkan agar berbakti dan berbuat baik kepad kedua orang tuanya. Dalam tafsir Al-Maraghi, berbuat baik ini tidak terbatas pada masa keduanya masih hidup, tapi sampai kematian mereka. Berbakti kepada orang tua merupaka amal yang paling utama dan sebaliknya, durhaka padanya termasuk dosa besar. ${ }^{11}$
Seperti diketahui bahwa berbakti kepada ibu bapaknya merupakan kewajiban yang kedua setelah keimanan. Anak harus ingat bagaimana seorang ibu mengandung, melahirkan, dan menyusuinya dengan susah payah tanpa mengharapkan balasan jasa dari anaknya. Semua itu yang menyebabkan ia berhak mendapat kemuliaan dan perlakuan yang baik dari anaknya. Kita sebagai anak yang berbakti wajib untuk membalas kebaikan kedua orang tua sebagaiman firman Allah: dan kami perintahkan kepada manusia supaya berbuat baik kepada ibu bapaknya, ibunyalah yang telah mengandungnya dengan susah payah dan melahirkannya dengan susah payah... (Al-Ahqaf / 46 :15 ).

Perhatian terhadap anak oleh syariat Islam dimulai sejak mereka masih dalam kandungan, yaitu ketika nabi menyuruh mencari pasangan yang baik. Perkawinan atas dasar inilah yang nantinya akan mencetak manusia- manusia yang berkualitas. Baik di sini mencakup agama nasab dan 
kehormatan calonnya. Karena perkawinan yang didasarkan azas ini yang akan melahirkan anak- anak yang suci dari segala segi yang bisa menyerap sifatsifat yang baik dan perilaku mulia.

Untuk menghasilkan keturunan yang baik, Islam mengajarkan agar anak yang masih berada dalam kandungan senantiasa mendapatkan asuhan dan perawatan hingga ia lahir. Pada tahap ini sang ibu memperhatikan kandungan dan dirinya yang bertujuan untuk memelihara kesehatannya dengan memperhatikan gizi dan makanan yang dimakan.

Demikian pula getaran kasih sayang yang berlimpah dapat dirasakan janin yang dikandungnya. Ibu yang mengandung dianjurkan untuk selalu memeriksakan kesehatannya pada dokter secara berkala dengan tujuan membangun kesehatan fisik dan jiwa anak dalam bentuk yang sempurna. Ketika anak masih dalam kandungan, ibu diperintahkan untuk memperhatikan kesehatannaya. Karena kesehatan ibu sangat mempengaruhi pertumbuhan dan perkemabangan janin, maka ada kewajiban agama yang ditangguhkan pelaksanaannya seperti puasa apabila pelaksanaannya diduga mengganggu kesehatan janin. ${ }^{12}$

\section{Kesimpulan}

Dalam perspektif Islam, setiap anak yang lahir ke dunia dibekali dengan berbagai bakat dan potensi yaitu kemampuan serta kebutuhan untuk berkembang secara psikologis. Setiap anak yang dilahirkan adalah membawa fitrah, yaitu potensi untuk menjadi baik dan sekaligus potensi untuk menjadi jahat. Selanjutnya tanggung jawab ibu bapaknyalah selaku orang tua yang mendidiknya hingga menjadi seorang yang baik atau seorang yang jahat. Adanya perhatian dan pemenuhan terhadap hak-hak bagi seorang anak akan menjadikan anak tersebut tumbuh dengan baik fisik maupun psikisnya. Sebaliknya kurangnya perhatian orang tua 
$\lim$ Fahimah

Kewajiban Drang Tua terhadap Anak dalam Perspektif Islam

dalam mengembangkan potensi dan bimbingan, akan mengakibatkan kurangnya keseimbangan pada jiwa anak. Oleh karena itu, orang tua yang baik harus senantiasa memberikan didikan yang bersumber dari ajaran agama yang akan membawa anak menjadi orang yang bermoral dan berbudi luhur.

${ }_{9}^{9}$ Zainuddin, Op. Cit. h. 30

10 Zakiyah Daradjat, perawatan jiwa untuk anak-anak, Jakarta: Bulan Bintang, 1976. h.469

${ }^{11}$ Ahmad Mustafa alMaraghi, Tafsir Al-Maraghi, Kairo : al-Halabi, 1946, h. 21 ${ }^{12}$ Dr. M. Quraish Shihab, Membumikan al-Qur'an: Fungsi dan Peran Wahyu dalam kehidupan Masyarakat, Bandung: Mizan, 1998, h. 255

\section{Refrensi}

${ }^{1}$ Dr. Abdullah Nashih

Ulwan, Pendidikan Anak Dalam Islam, Jakarta: Pustaka Amani, 1995, h. 68

2 Ibnu Qayyim al-Jauziyah, Mengantar Balita Menuju Dewasa, Jakarta: Serambi Ilmu Semesta, 2001, h. 193

${ }^{3}$ Zainuddin, Op. Cit. h. 28

${ }^{4}$ Zainuddin, Op. Cit. h. 26

${ }^{5}$ Zainuddin, Op. Cit. h. 28

${ }^{6}$ Tim penyusun kamus

pusat pembinaan dan

pengembangan bahasa, Kamus

Besar Bahasa Indonesia, Jakarta: Balai

Pustaka, 1995, h. 35

Prof. Dr. J.S. Badudu dan

Sutan Mohammad Zain, Kamus

Umum Bahasa Indonesia, Jakarta:

Pustaka Sinar Harapan, 1996, h. 44

Zainuddin, Anak dan

Lingkungan Menurut Pandangan

Islam, ttp: CV. Andes Utama Prima, 1994, h. 18 